\title{
Spider burrows in ichnological context: a review of literature data and burrows of the wolf spider Trochosa hispanica Simon, 1870 from Albania
}

\author{
Alfred Uchman ${ }^{1} \cdot$ Blerina Vrenozi ${ }^{2} \cdot$ Bardhyl Muceku $^{3}$
}

Received: 28 September 2017 / Accepted: 29 November 2017 / Published online: 22 December 2017

(c) The Author(s) 2017. This article is an open access publication

\begin{abstract}
A general review of spider burrows and history of their research in eighteenth to nineteenth centuries are provided on the basis of the literature, which is dispersed and almost forgotten by majority of ichnologists. Moreover, burrows of the wolf spider Trochosa hispanica Simon, 1870 from a mountain meadow in Albania are presented. They are composed of an almost straight through gently curved to slightly winding vertical shafts $(8.2-17.2 \mathrm{~mm}$ in diameter) with a basal, oval chamber, which is $14.5-30.6 \mathrm{~mm}$ wide. Above the ground level, some of them show a low, agglutinated chimney a cone composed of soil granules. The burrows are 83-235 mm long. They are comparable with the trace fossil Macanopsis Macsotay, 1967. Other spider burrows can form a simple shaft, which may be ascribed to the ichnogenus Skolithos Haldeman, 1840, or a shaft with the side oblique branches, which is is similar to the ichnogenus Psilonichnus Fürsich, 1981. Many spider burrows show one or more chambers. Their outlet may be closed with a trapdoor or show a chimney sticking above the ground. They may show scratch traces running parallel to the burrow. The burrows are domiciles in which spiders spend a part of, or even the whole life. They protect spiders against harsh environmental conditions, foremost against too low or to high temperature, sheet floods, or predators. Moreover, they can be also a place for copulation, oviposition, parental care, placement of cocoons, or shedding the exuvia. Burrowing spider are more common in in warmer climatic zones, in open space, above the water ground level, and less common in flooded. So far, very few examples of fossil spider burrows are recognised, mostly in Cenozoic sediments, even if spiders are known since the Carboniferous.
\end{abstract}

Keywords Ichnology $\cdot$ Trace fossils $\cdot$ Continental environments $\cdot$ Arachnids

\section{Introduction}

Considerable advances in continental palaeoichnology were effectuated among others through neoichnological research as proven in many papers by the latest 20 years (e.g., Hasio-

Alfred Uchman

alfred.uchman@uj.edu.pl

Blerina Vrenozi

bvrenozi@gmail.com

Bardhyl Muceku

bardhyl.muceku@fgjm.edu.al

1 Institute of Geological Sciences, Jagiellonian University, Gronostajowa 3a, 30-387 Kraków, Poland

2 Research Center of Flora and Fauna, Faculty of Natural Sciences, Tirana University, Rr. Petro Nini Luarasi 80, Tirana, Albania

3 Faculty of Geology and Mining, Polytechnic University of Tirana, Rruga Elbasanit, Tirana, Albania tis 2002; Genise 2004). More and more groups of organisms receive their neoichnological characteristics, but many of them are still awaiting more attention. Among them, arachnids, including spiders, are known as producers of trackways and burrows. Fossil trackways of arachnids are known from the paper by Alf (1968) and recent trackways from some experiments (Davis et al. 2007; Schmerge et al. 2013). More is known about their burrows, foremost these produced by spiders. However, their descriptions, drawings, and rarely, photographs are dispersed in the literature, usually as additional information in biologically oriented publications, mostly in the nineteenth century (e.g., Moggridge 1873, 1874) and later (e.g., Bryson 1939; Gertsch 1949; Coyle 
1971; Ahlbrandt et al. 1978; Decae 1995, 1996). Only in the latest years, spider burrows got more attention as ichnological objects (Hils and Hembree 2015). However, this topic is still poorly known even among specialists on continental ichnology.

Fossil counterparts of spider burrows are poorly known from single occurrences only and referred to the ichnogenera Skolithos if they are simple shafts (Fernandes et al. 1992) or Macanopsis if they are terminated with the basal chamber (Hasiotis 2002). However, a large taxonomic diversity of burrowing spiders (only the family Lycosidae embraces about 124 genera and 2419 species in a wide range of habitats, as for 31.10 .2017 ) poses a question about diversity of their burrows. Some authors are of the opinion that the spider burrow morphology is foremost taxon-specific (e.g., Coyle and Icenogle 1994), but others refer their shape mostly to palaeoenvironmental factors (e.g., Hils and Hembree 2015).

This paper contributes to a better understanding of neoichnology of spiders by (1) a review of old (mostly eighteenth and nineteenth centuries) and newer literature data, in order to show morphology of the spider burrows in an uniform way; such extensive review was never done, (2) to present a case study of modern burrows of Trochosa hispanica Simon, 1870, from Albania on the basis of burrow casts and field observations, and (3) to summarise the state of knowledge on spider burrows in in ichnological context.

The history of published observations of spider burrows is very long, with applications of taxonomic names, which in large part were revised. For clarity of the text, only the current names listed in the World Spider Catalog (2017) are used in this paper. All taxa discussed in this paper (with old names and the revised names, according to the catalog mentioned) and their families are listed in Appendix 1.

\section{Some eighteenth and nineteenth century observations on spider burrows}

Several data on spider burrows are dispersed in the old literature, mostly forgotten and unknown for most specialists on invertebrate ichnology and neglected by biologists. Therefore, it is worthy to recall the data, which can contribute to the history of neoichnology and still are a source of information. Some of the burrows are shown in Figs. 1, 2 and 3.

Probably the oldest illustration of spider burrows comes from the book by Browne (1756) who illustrated a simple vertical shaft with a two-valve trapdoor from Jamaica and referred it to "the black tarantula" (Fig. 1). Taxonomy of the spider producer was a matter of controversy discussed by Westwood (1842), who illustrated the upper part of some other spider burrow with a trapdoor produced by Ummidia aedificatoria (Westwood, 1840) (his pl. 10, figs. 24, 25).

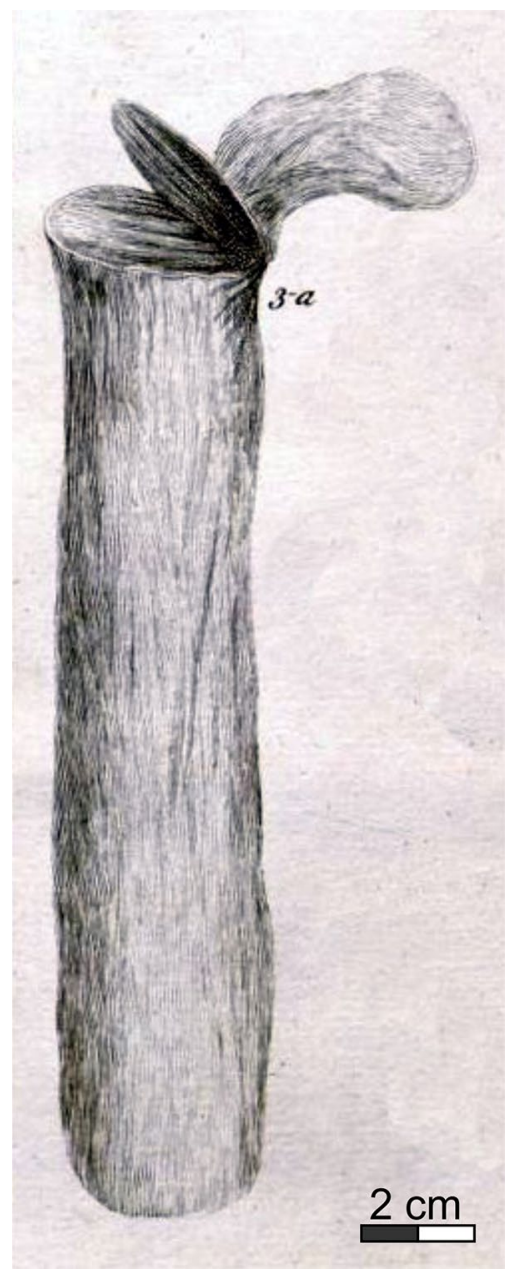

Fig. 1 The probably oldest illustrated and described spider burrow by Browne (1756) referred to "the black tarantula", Jamaica

Audouin (1833, pl. 4, 1837, pl. 3) presented some trapdoor spider burrows from the southern France and Corsica. Saunders (1842a, pl. 9, figs. 9-14) described 10-15 cm deep burrows of Cyrtocarenum cunicularium (Olivier, 1811) from the island Corfu in Greece and illustrated their parts with a trapdoor. Probably Saunders (1842b) was the first who made experiments with burrowing spiders; he observed burrows of Cteniza sauvagesi (Rossi, 1788) in a container with earth in his balcony.

Moggridge (1873) provided descriptions and very good illustrations of some trapdoor spider burrows from the southern France. They include a straight, oblique shaft without chamber produced by Cteniza sauvagesi (Rossi, 1788) (Fig. 21), a curved, slightly steepened down shaft of Nemesia eleanora O. Pickard-Cambridge, 1873 (Fig. 2a), a curved, distinctly steepened down shaft of Nemesia caementaria (Latreille, 1799) (Fig. 2a), and an oblique, almost straight main shaft with two trap doors and a blind, up-going side shaft produced by Nemesia manderstjernae L. Koch, 1871 


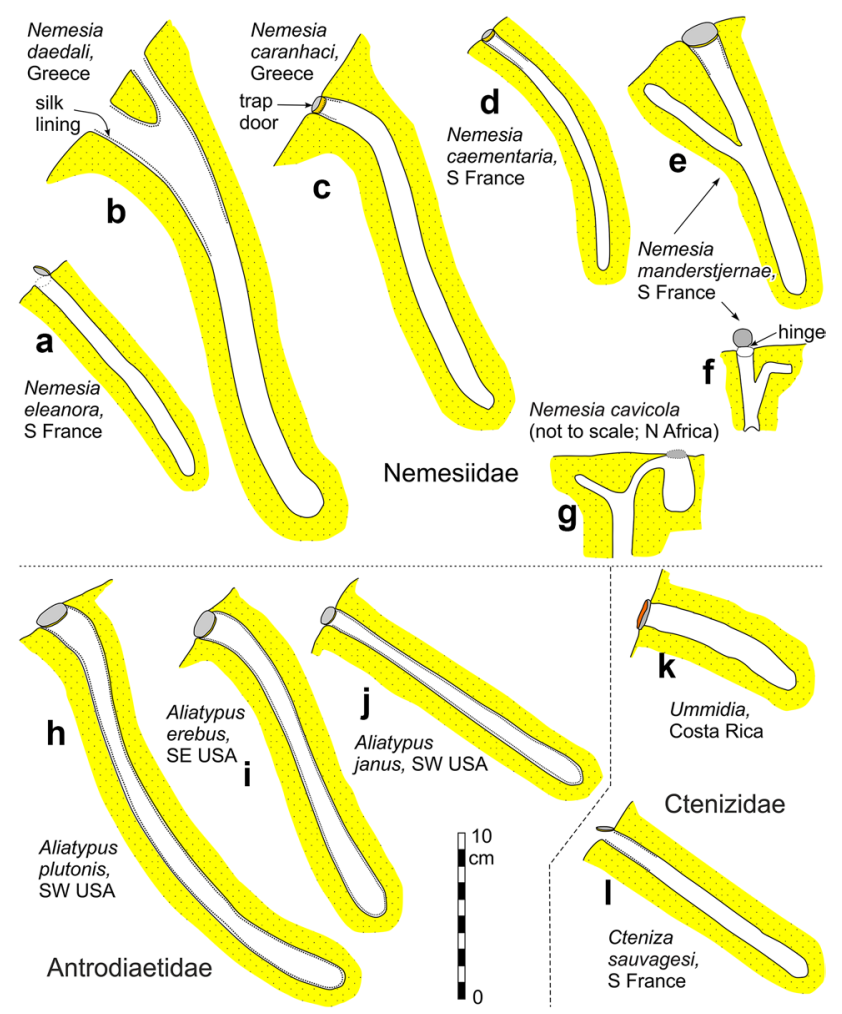

Fig. 2 Trapdoor spider (families Nemesiidae, Antrodiaetidae, Ctenizidae) burrows. The same scale for all drawings; a Nemesia eleanora O. Pickard-Cambridge, 1873 (Moggridge 1873, pl. 12, fig. A); b Nemesia daedali Decae, 1995 (Decae, 1995, fig. 5); c Nemesia caranhaci Decae, 1995 (Decae 1995, fig. 11); d Nemesia caementaria (Latreille, 1799) (Moggridge 1873, pl. 8, fig. A); e, f Nemesia manderstjernae L. Koch, 1871 (Moggridge 1873, pl. 9, fig. A and pl. 11, fig. B1); g Nemesia cavicola (Simon, 1889) (McCook 1890, Fig. 1); h Aliatypus plutonis Coyle, 1974 (Coyle and Icenogle 1994, fig. 18h); i Aliatypus erebus Coyle, 1974 (Coyle and Icenogle 1994, fig. 18i); j Aliatypus janus Coyle, 1974 (Coyle and Icenogle 1994, fig. 18c); k Ummidia Thorell, 1875 (Bond and Coyle 1996, fig. 6); 1 Cteniza sauvagesi (Rossi, 1788) (Moggridge 1873, pl. 7, fig. A)

(Fig. 2e, f). From Morocco, Moggridge (1874, pl. 13, fig. B) illustrated the upper part of the burrow of Nemesia elongata (Simon, 1873) which shows protruding silk funnel hung on plants, and a few Atypus burrows (his pl. 14), including a burrow of Atypus piceus (Sulzer, 1776) with a short side shaft diverging up and down (Fig. 3n) and a bifurcating shaft of Nemesia dubia O. Pickard-Cambridge, 1874 (his pl. 17). Before, Simon (1873) illustrated a burrow of Atypus piceus (Sulzer, 1776) from France, which shows a basal chamber and long silk tube lying on the ground (Fig. $3 \mathrm{~m}$ ).

McCook (1885, fig. 44) in his popular, well-illustrated book, showed a vertical shaft with an agglutinated chimney, which is up to $50 \mathrm{~mm}$ high, produced by the North American Geolycosa turricola (Treat, 1880). McCook (1888) presented a vertical to curved, silk-lined shafts, about $20 \mathrm{~mm}$ in diameter, $13-15 \mathrm{~cm}$ deep, with a long silk tube coming out from the shaft and attached to trees or other objects, and

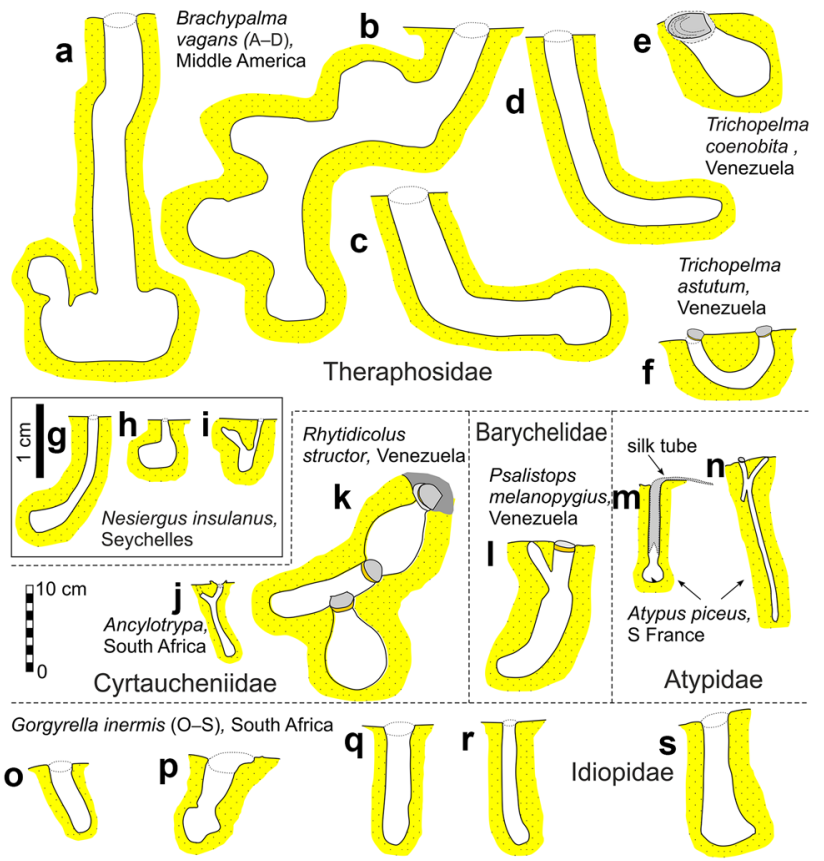

Fig. 3 Spider burrows (families Theraphosidae, Cyrtaucheniidae, Barychelidae, Atypidae, Idiopidae) re-drawn from the literature. The same scale for all drawings, except for $\mathbf{g - i}$. a-d Brachypelma vagans (Ausserer, 1875) (Machkour M'Rabet et al. 2007, fig. 3); e Trichopelma coenobita (Simon, 1889) (Simon 1899, pl. 1, fig. 4); f Trichopelma astutum (Simon, 1889) (Simon 1899, pl. 1, figs. 5, 6); g-i Nesiergus insulanus Simon, 1903 (Simon 1903a); j Ancylotrypa Simon, 1889 (Leroy and Leroy 2005, fig. 1.2); k Rhytidicolus structor Simon, 1889 (Simon 1889, pl. 2, fig. 3); I Psalistops melanopygius Simon, 1889 (Simon 1899, pl. 3, fig. 1); m Atypus piceus (Sulzer, 1776) (Simon 1873, pl. 4); n Atypus piceus (Sulzer, 1776) (Moggridge 1874, pl. 19, fig. A); o-s Gorgyrella inermis Tucker, 1917 (Hils and Hembree 2015, figs. 13.1, 12.1, 14.3, 14.1, 14.2)

with an occasional terminal chamber with side, blind tunnels. They belong to the purseweb spider Sphodros abboti Walckenaer, 1835 known from SE USA (see also Poteat 1890). In the same paper, McCook (1888) provided a short review of different trapdoor spider burrows presenting simple drawings, which show simple vertical shafts with tumulus produced by Mygalidae (they include "tarantulas") and shafts with silk tubes protruding from the shaft and attached to plants in vertical or lying position (produced by among others by Atypus piceus (Sulzer, 1776)).

McCook (1890) illustrated the upper part of the Nemesia cavicola (Simon, 1889) burrow from North Africa: it shows a shallow chamber with a side tunnel in its upper part, which turns down to the main shaft having an up-going side shaft (Fig. 2g). Simon (1899) illustrated atypical U-shaped burrow with trapdoors at two openings, produced by Trichopelma astutum (Simon, 1889); he also presented an oblique amphora-like burrow with a trapdoor, made by Trichopelma coenobita (Simon, 1889) (Fig. 3e), a three-chamber burrow of Rhytidicolus structor Simon, 1889 with two internal 
trapdoors (Fig. 6k), and curved flask-shaped burrow with a side shaft, produced by Psalistops melanopygius Simon, 1889 (Fig. 31). Hancock (1899, pl. 2) illustrated burrows of Geolycosa domifex (Hancock, 1899) which shows a chimney and terminal chamber; its winding course adjusts to stones in soil (Fig. 4f).

\section{General remarks on spider burrows}

Information on the spider burrows is collected in this section, and some of the burrows are illustrated (Figs. 2, 3, 4). The focus is on the morphology, function, and environmental meaning, which are the most important features for ichnologists.

Most of the spider burrows are produced by members of the families Ctenizidae (trapdoor spiders), Lycosidae (wolf spiders), Antrodiaetidae (folding trapdoor spiders), and Theraphosidae (tarantulas) (Ratcliffe and Fagerstrom 1980), but members of other families, including Sparassidae (Nørgaard 2005), Filistatidae (Birkhofer and Moldrzyk 2003), Heteropodidae (Henschel 1990), Eresidae (Lubin and Henschel 1990), Cyrtaucheniidae (Leroy and Leroy 2005), Segestriidae (Costa et al. 1993; Conti et al. 2015), Nemesiidae, Atypidae, Idiopidae, Barychelidae, and others are also burrowing spiders. Most of the burrows are vertical or oblique shafts (called also tubes or nests in the arachnological literature), with or without terminal chamber, but usually slightly enlarged toward the base, usually lined partly or completely with silk for stabilisation of the burrow margins. Thicker silk lining is present in less stable sediments (Hils and Hembree 2015). A single, usually oblique side shaft, which may be blind, corked, rarely open, or additional, internal chamber(s) can be present. The presence/ absence of the side shaft can be intraspecific feature (Decae 1996; see also Figs. 2, 3, 4). Gertsch (1949) illustrated a shaft of Cyclocosmia which is widest in the middle part. Spiders need a widened part for turning. Scratch traces running parallel to the burrow can be present (Hils and Hembree 2015).

The burrows can be very small, even less than a centimetre deep, as for Nesiergus insulanus Simon, 1903 from Seychelles (Fig. 3g-i), or they can be very large, as for the bird spider Brachypelma vagans (Ausserer, 1875) from the Central America, which can show no chamber, one chamber or a few chambers (Fig. 3a-d), and can be up to $45 \mathrm{~cm}$ deep. Other bird spider Trichopelma astutum (Simon, 1889) produces U-shaped burrows without chambers (Fig. 3f). Bates (1864, p. 57) reported burrows of Theraphosa blondi (Latreille, 1804) from Amazonia, which makes inclined burrows $60 \mathrm{~cm}$ deep. Size of the same taxon burrows is positively correlated with the body size (e.g., Corey 1991), which can be different between male and female and can depend on the age (Fig. 4i-k; Albín
Fig. 4 Spider (family Lycosidae) burrows re-drawn from the literature. The same scale for all drawings. a, b Geolycosa xera archboldi McCrone, 1963 (Carrel 2008, fig. 1). c, d Geolycosa hubbelli Wallace, 1942 (Carrel 2008, fig. 1); e Geolycosa missouriensis (Banks, 1895) (Suter et al. 2011, fig. 1); f Geolycosa domifex (Hancock, 1899) (Hancock 1899, pl. 2); g Lycosa Latreille, 1804 indet. (Ratcliffe and Fagerstrom 1980, fig. 1b); h Lycosidae Sundevall, 1833 indet. (Hasiotis and Bourke 2006, fig. 8); i-k Allocosa brasiliensis (Petrunkevitch, 1910) (Albín et al. 2015, fig. 1; burrows of female, male and juvenile, respectively); l-n Hogna lenta (Hentz, 1844) (Hils and Hembree 2015, figs. 6.3, 13.3, 14.4)

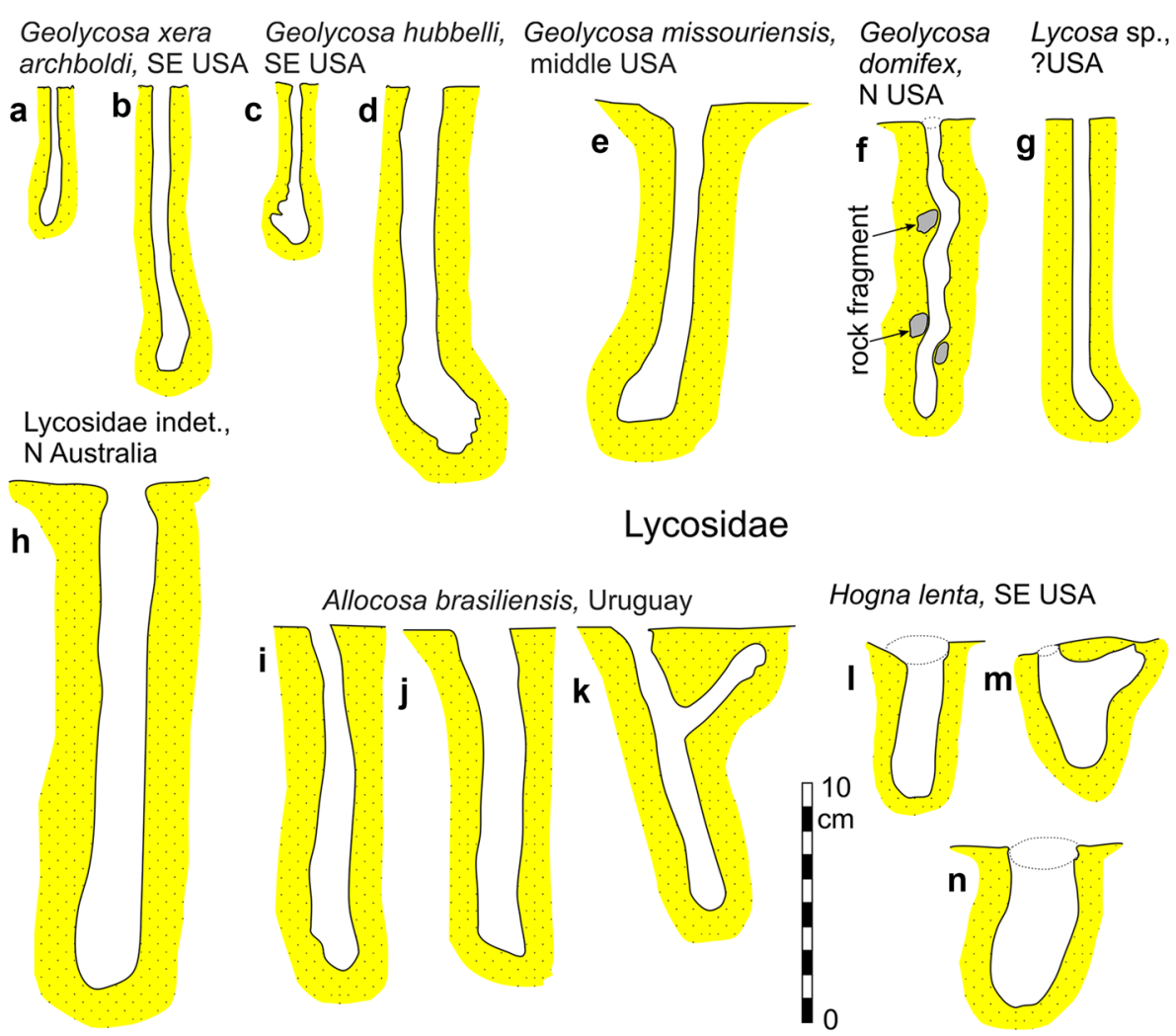


et al. 2015; De Simone et al. 2015). For instance, males of the Aliatypus species make smaller burrows than females (Coyle and Icenogle 1994). Usually, the burrow depth is positively correlated with burrow diameter (e.g., Miller and Miller 1984; Bradley 1996; Carrel 2003). Burrow depth can depend also on aridity of the substrate; deeper burrows are produced in more arid conditions (Coyle and Icenogle 1994). Burrow can be dug out by means of chelicerae, palps (e.g., Henschel 1990; Birkhofer and Moldrzyk 2003), front legs or combinations of them (e.g., Hamilton et al. 2012 and references therein), by male or female, or both. The tarantula Aphonopelma hentzi (Girard, 1852) uses silk bags to take excavated soil out of its burrow (Formanowicz and Ducey 1991).

The entrance to the shaft can be closed by a thin (wafer, valve) to thick (cork) trapdoor, which is attached by a hinge to the entrance edge (Ctenizidae). Additional trapdoors can be inside the burrows. The burrows can be closed by different plugs, including spherical bodies (Leroy and Leroy 2005). The entrance can be surrounded by a tumulus cone composed of granules of the excavated ground deriving from the burrow. Usually, the entrance is located at the top of the cone and can be reinforced by a silk lining. Exceptionally, entrances to burrows of Ariadna (family Segestriidae) from the Namib Desert are surrounded by 4-11 small pebbles (Costa et al. 1993). The shaft can be prolonged over surface into an agglutinated chimney (turret in the arachnological literature). The silk lining can prolong outside the burrow as a silk pipe or funnel, which can lie on the ground or plants, or can be attached to plants or other objects. Some burrows of spiders from the family Filistatidae show radial ditches on the stretching from the burrow entrances the sand surface (Birkhofer and Mildrzyk 2003). Remnants of prey (mostly herbivorous insects, other arachnids, and many other groups of small, terrestrial invertebrates, see, e.g. Coyle 1971; Coyle and Icenogle 1994), exuvia, eggs, and cocoons can be expected within the burrows.

The burrows can be produced on horizontal or inclined surfaces (Figs. 2, 3, 4) in soil, sand or sand and gravel in different humidity conditions and vegetation cover, however, with a tendency to open areas. Their distribution can be controlled by microhabitats, which can be taxonomic specific (e.g., Carrel 2003; Birkhofer and Moldrzyk 2003). Places rich in food, with lesser danger of flooding or erosion are preferred (Coyle 1971). For instance, burrows of the bird spider Brachypelma vagans (Ausserer, 1875) are produced only in clayey soils (Machkour M'Rabet et al. 2007). Spiders prefer places where the lower part of their burrows is in a humid substrate (Coyle 1971). Commonly, the burrows occur in patches (e.g., Coyle 1971; Coyle and Icenogle 1994; Bradley 1996; Canning et al. 2014; Gupta et al. 2015) and burrows of young spiders are located close to the burrows of adults (Coyle and Icenogle 1994; Bond and Coyle 1995).
The burrows play very important role in biology of the burrowing spider, which can spend a part of or even the whole life in one burrow, e.g. Geolycosa xera archboldi McCrone,1963 (Marshall 1995). The burrow is a protection against harsh environmental conditions, foremost against too low or to high temperature, sheet floods, predators (e.g., Decae 1996) or fire (Carrel 2008). Burrows offer more stable temperature (e.g., Aisenberg et al. 2011; Aisenberg and Peretti 2011; Chikhale and Santape 2015), and the temperature changes along the burrow; this allows a spider to stay in the optimal position (Humphreys 1978). Against flooding, spiders can build chimneys, close the external or internal trapdoors, plug the burrow, or they construct side shafts or internal chambers, which can be also closed by internal trapdoors. Burrows of Nemesia cavicola (Simon, 1889) from North Africa have an initial chamber with further passage in the upper part and a side shaft (Fig. $2 \mathrm{~g}$ ) for protection against running water (McCook 1890). Protection of burrows against sheet flood by means of internal or external trapdoor(s), building of chimney, blocking, escape side shafts or supplementary chambers with doors is a part of spider habits (Main 1993).

Burrows can be blocked by spiders against predators or parasites (Decae 1996). The parasites, for instance, include centipedes, pompilid wasps, acrocerid flies, and mites (Coyle 1971; Coyle and Icenogle 1994). The chimney in burrows of Lycosa tarantula (Linnaeus, 1758) can be also a protection against scorpions (Williams et al. 2006). Trichopelma astutum (Simon, 1889) from Venezuela can escape through one trapdoor closed entrance of its U-shaped burrow (Fig. 3f; Simon 1889; McCook 1890). Burrows of Geolycosa can be modified by the pampilid sand wasp Anoplius, which prays on the spider and digs a side horizontal tunnel in the middle of the spider burrow (Gwynne 1979).

Burrows can be also a place for copulation, oviposition, parental care (e.g., Aisenberg et al. 2011; Aisenberg and Peretti 2011), placement of cocoons, or shedding the exuvia (Albín et al. 2015 and references therein). Females can select males by the length of their burrows (Aisenberg and Peretti 2011). Spiders can wait in the burrow for a pray; they can be connected by a tread to the web above (Lubin and Henschel 1990).

Generally, preservation of spider burrows is possible by filling of transported sediments. This is possible foremost in fluvial settings; however, spiders use to select places free of such events. Modern spider burrows sealed with mud in Australia have been mentioned by Main (1978). In aeolian environments, sediment can be blown by wind into the burrow. The presence of silk lining is a factor increasing the preservational potential. 
Fig. 5 The study area and entrances to the burrows. a general view to the pasture and the karst depression in the middle, where the burrows occurred; $\mathbf{b}$ entrance with the soils tumulus cone; $\mathbf{c}$ entrance with the soils tumulus and the chimney; $\mathbf{d}$ entrance with the silk reinforced chimney

\section{Burrows of Trochosa hispanica Simon, 1870}

\subsection{Location and environment}

Modern burrows of Trochosa hispanica Simon, 1870 have been observed in Albania. Preliminary results were presented on a conference (Uchman et al. 2015). The burrows occur in a silty soil showing low content of organic matter and filling a karst depression in a mountain meadow (glade) with scattered deciduous trees (Fig. 5), east of Tirana, on the western slope of Dajti Mt. (N41 ${ }^{\circ} 22.170^{\prime}$; E19 ${ }^{\circ} 54.315^{\prime}$ ) at the altitude of $1040 \mathrm{~m}$ a.s.1., located a few hundred metres NE from the terminal cable car station The karst depression shows more or less horizontal surface, with only small roughness, partly of anthropogenic origin. The floor of the depression is lowered for about a half metre in respect to the grassy area of the surrounding meadow, which is slightly sloping to the sunny western side. The soil in the depression is brown-grey or grey in colour, classified as rhodic luvisols (Zdruli et al. 2002). It shows a granulated structure and contains infrequent fragments of Cretaceous karstified limestones and other rocks of variable size. The soil was partly cracked during the first observations. A small fragment of the white, karstified Cretaceous limestone bedrock is exposed in the eastern part of the depression. The study site was poorly vegetated with a scattered grass and a few lower plants. The glade is attended by cattle and humans. The depression is a non-shadowed place during the days, except for early mornings at certain times of the year.

The area lies in the northern Mediterranean premountainous climatic region. The climate is characterised by dry summers and wet winters, with annual precipitation up to 1200-2000 mm, which may be locally very diverse. The snow cover usually lies from December to March and it is $40-80 \mathrm{~cm}$, locally up to $2 \mathrm{~m}$ thick. The annual average temperatures amplitudes range from 15 to $22{ }^{\circ} \mathrm{C}$ during the summer, to under $0{ }^{\circ} \mathrm{C}$ during the winter. The precipitations are very variable, depending on the relief, with more rainy western slopes and drier eastern slopes (Grup Autorësh 1990). The vegetation in the Mt. Dajti western slope changes with the altitude. Up to 500-600 $\mathrm{m}$ a.s.1., there is the Mediterranean maquis; from 500-600 $\mathrm{m}$ up to 900-1100 $\mathrm{m}$ a.s.l. lies the oak zone (a series of mountain glades, including the study site is located in the upper part of this zone); above, the European beech (Fagus sylvatica L.) and the coniferous forests are present (Grup Autorësh 1991).
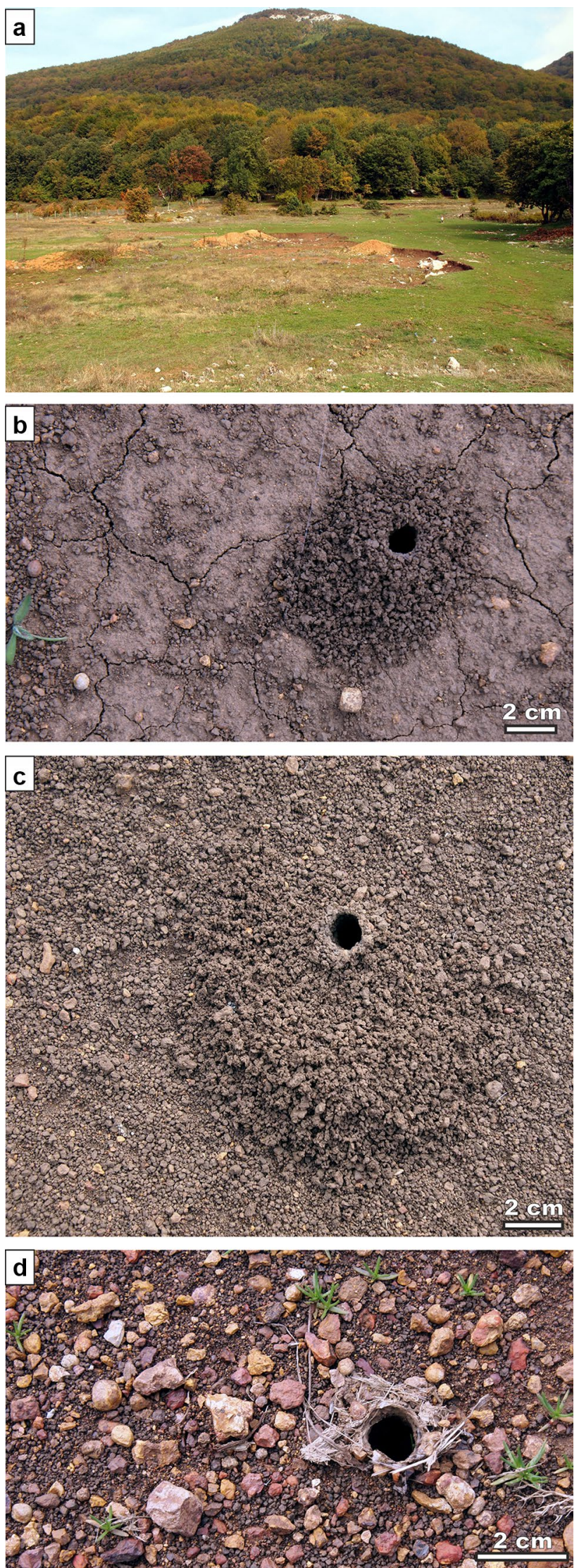
The field work was performed at the beginning of October 2013 and at the end of September 2014. Surface features of the spider burrows have been observed and documented. Seventeen complete burrows have been casted in building cement, which has been poured into the burrows. The cement hardened slowly. The casts have been dag out after a few days, cleaned, measured, and photographed. The trace making spiders from some burrows have been captured for determinations. The casts are stored at the Institute of the Geological Sciences, Jagiellonian University in Kraków (institutional abbreviation INGUJ241P).

\subsection{Burrows}

The burrows are simple, vertical, cylindrical shafts terminated at the base in a chamber (Fig. 6). The shaft course ranges from almost straight through gently curved to slightly, irregularly winding. Its horizontal section is circular, 8.2-17.2 $\mathrm{mm}$ in diameter (mean $11.2 \mathrm{~mm}, n=17$ ). The shaft can show small, irregular swellings. Some of the burrows display a low, agglutinated chimney being a prolongation of the shaft above the ground surface. The chimney is composed of soil granules and dry grass fragments, which are bound together by silk (Fig. 5d). The entrance to the burrow can be surrounded by a cone of the ground tumulus composed of soil granules (Fig. 5b-c). The cone is symmetrical or asymmetrical, $5-10 \mathrm{~cm}$ in diameter and up to $2 \mathrm{~cm}$ high. A few entrances were closed with silk. The surface surrounding the entrance is horizontal or subhorizontal. The burrows were located more or less a metre apart and clustered in an area of $100-200 \mathrm{~m}^{2}$, which was limited to the less vegetated part of the karst depression.

The chambers are vertically elongated, symmetric or asymmetric bulb-shaped. The transition from the shaft to the chamber is gradual that most burrows have the baseball bat shape. Less frequently, the chambers are well differentiated from the shaft by a distinct but gradual increase in diameter at a short distance. In such case, the chamber occupies $10-15 \%$ of the total burrow length. Most of the chambers are slightly elliptical in horizontal section, which perimeter is located $18-63 \mathrm{~mm}$ from the base (mean $=28 \mathrm{~mm} ; n=17$ ) from the base. Their maximum width ranges from 14.5 to $30.6 \mathrm{~mm}$ (mean $23.6 \mathrm{~mm} ; n=17$ ). In a few specimens, the chamber displays two or three swellings. The base of the chambers is hemispherical in shape or blunt. The blunt bases are oblique, uneven surfaces. They are probably an artefact caused by asymmetric filling of the chamber base by fallen soil before or during casting of the burrow. The main axis of the chamber follows the main axis of the shaft or it is inclined at an angle of up to $30^{\circ}$, exceptionally $45^{\circ}$ in respect to the shaft axis.

The burrow margin is slightly uneven, without bioglyphs, only rarely with some very short, irregular protrusions showing blind endings. Inside some casts, vertically elongated, semi-opened, hollow chambers, smooth inside, are present. They were occupied by the tracemaking spiders when the casts were dug out. The chamber occupied most of the burrow outline. Therefore, the cast was easily broken in such a place.

The burrows are 83-235 mm long in total (mean $149 \mathrm{~mm}$, $n=17)$. Relations between the morphometric parameters of the burrows are shown in Fig. 7. The length of the burrow is only slightly correlated with the diameter of shafts and chambers.

\subsection{The tracemaker - Trochosa hispanica Simon, 1870}

Trochosa hispanica Simon, 1870 was described for the first time by Simon (1870). According to Thaler et al. (2000), $T$. ruricola rustica Thorell, 1875 is considered as a junior synonym of T. hispanica. As T. manicata Thorell, 1875 stands as a junior synonym of this species, $T$. hispanica is considered as Holomediterranean species, widespread in most of the Mediterranean region, ranging to southern border of the Alps in the north (Thaler et al. 2000; World Spider Catalog 2017).

Trochosa hispanica is morphologically easily distinguishable from other species of this genus, as its head is narrower and longer; the striated summit protrudes and continues till the two small furrows, which obliquely intersect the thorax and are more profound. The integument is dark tawny-red in colour. The eyes are placed in a black horseshoe band, but the middle eyes area is tawny. Two long and wide parallel brown bands run from the sides of face to almost the thorax, which has an oval outline at males and it is barely truncated above the pedicle. Looking at male legs, tarsus is long and thin and the pedipalp has claw on a cymbial tip. Males are identified by yellowish tarsi, thin, long and irregular hairs of metatarsus and tarsus, tibia mostly with white hairs or hairy spots and by distinctly annulated femora. The genitalia also appear with different features. In contrast to all other Central European Trochosa species, T. hispanica has uniquely formed, long, and nearly parallel dark markings from the anterior to the transverse pockets of the vulva. The epigyne has chitinised arcs at anterior margin of epigynal groove, touching each other. The male palpal organ (embolus) displays a rolled-up tip (Simon 1870; Thaler et al. 2000; Hepner and Milasowszky 2006; Nentwig et al. 2016).

In Albania, Trochosa hispanica occurs in the eastern part of the country in the Stëblevë area (Librazhd district) and in the central Albania in the Tirana district, from lower altitudes up to Dajti Mountain (Vrenozi and Deltshev 2012; Vrenozi and Jäger 2012). Adult males of T. hispanica were found widespread almost during all the year, in humid 


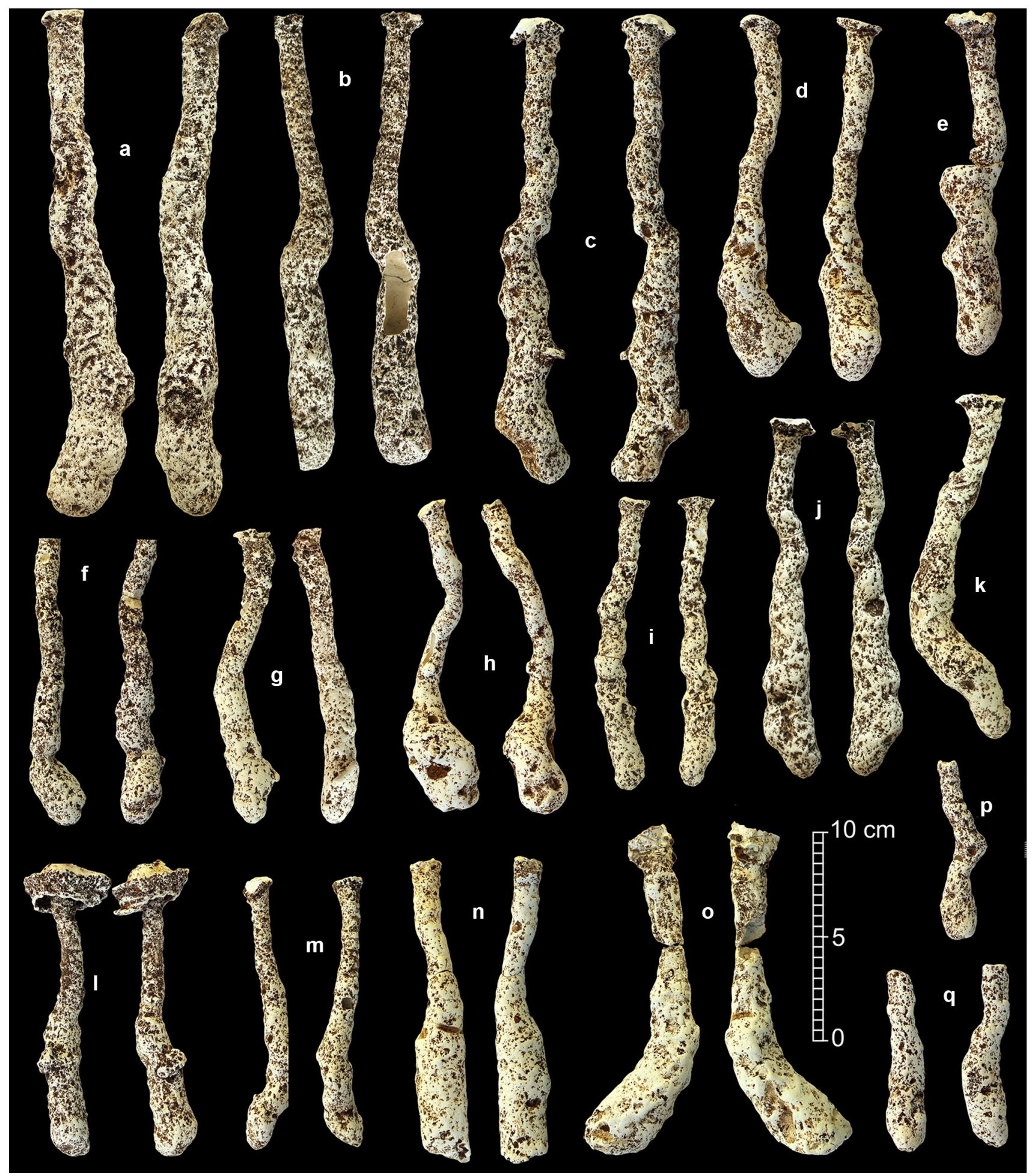

Fig. 6 The cement casts of burrows of Trochosa hispanica in from two different sides (except for E, $\mathrm{K}$ and $\mathrm{P}$ showing the burrows from one side). a INGUJ229P40; b INGUJ229P41; c INGUJ229P42; d INGUJ229P47; e INGUJ229P52; f INGUJ229P44; g INGUJ229P53; h INGUJ229P54; i INGUJ229P46; j INGUJ229P45; INGUJ229P51; l INGUJ229P50; m INGUJ229P48; n INGUJ229P56; o INGUJ229P55; p INGUJ229P49; q INGUJ229P58 


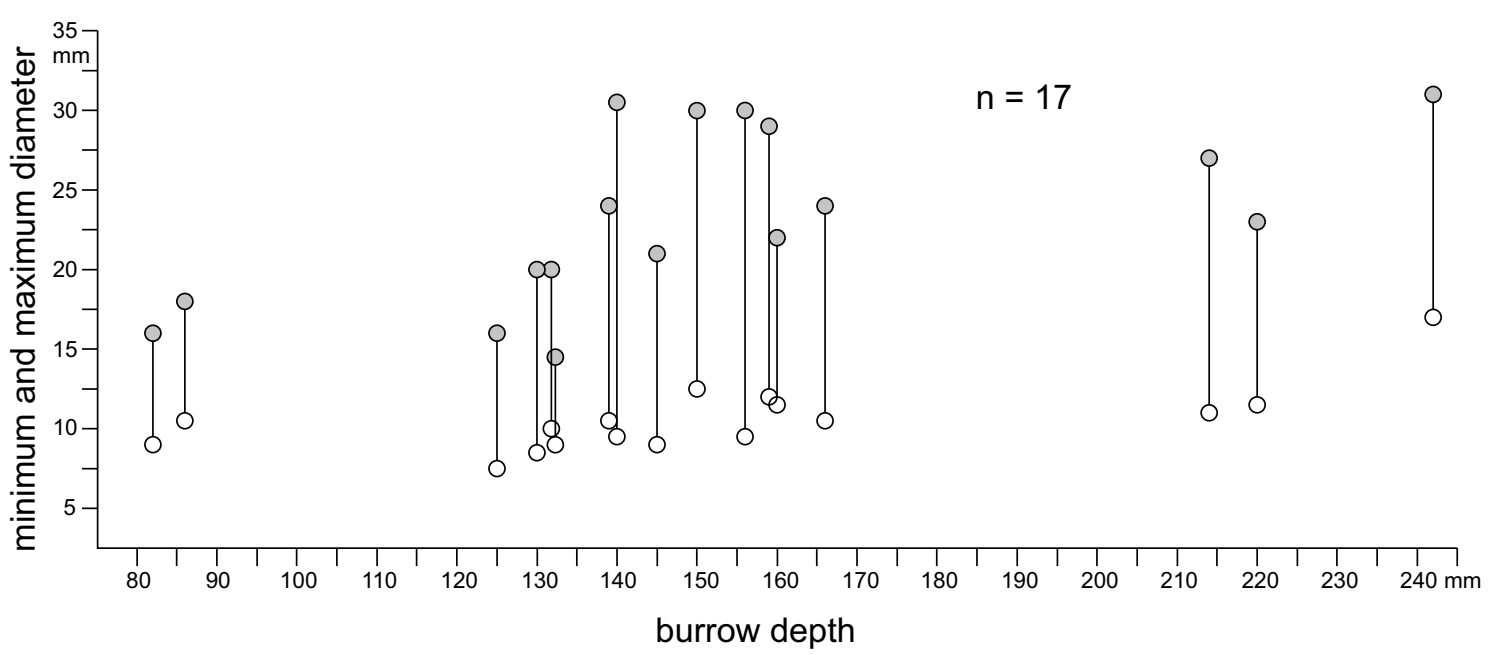

Fig. 7 Measurements of the Trochosa hispanica burrows

places of different habitats, including grassy meadows or even the humus of Fagus sylvatica near a stream in the Dajti Mountain.

It was known so far that Trochosa species belong generally to the non-burrowing wolf spiders feeding on insects, which built shallow silky retreats; only some of them are known to produce burrows (Nentwig et al. 2016). However, it was shown by the present study that Trochosa hispanica is a deep burrower.

\section{Fossil record of spider burrows}

Although spiders are known since the Carboniferous (Penney and Selden 2011), fossil evidence of spider burrows is very poor. Dunlop and Braddy (2011) revised Sabella bavincourti Vaillant, 1909 from the Eocene of northern France, interpreted by Leriche (1910) as a burrow of the spider Cteniza. This is a piece of rock perforated by two larger, circular holes, which do not display any feature of spider burrows. Dunlop and Braddy (2011) ascribed Sabella bavincourti Vaillant, 1909 to Oichnus Bromley, 1981, but Oichnus is a boring in skeletal substrates. So, this assignation is unfortunate and in fact unnecessary as the original specimen does not represent any determinable trace fossil and can be treated as the nomen dubium (Wisshak et al., 2015).

Fernandes et al. (1992) presented Skolithos sp., an about $25 \mathrm{~cm}$ deep, slightly curved, club-shaped burrow from MioPliocene fluvial sediments of Brazil and referred it to wolf spiders. Probably, more fossil burrows like this are hidden under the ichnogenus Skolithos in papers on continental sediments, for instance, Skolithos from the Holocene coastaldune eolianites of San Salvador in Bahamas (Curran and White 1991; Buatois and Mángano 2011, fig. 11.4c). Also the Permian Skolithos, $0.5-2 \mathrm{~cm}$ in diameter and up to $30 \mathrm{~cm}$ deep, from fluvial sediments of Antarctica (Fitzgerald and Barret 1986), can be produced by spiders. Spiders are also considered as candidate producers of Cylindricum Linck, 1949 (e.g., Smith et al. 2008) which is included by some researcher in Skolithos (Alpert 1974).

A tapering up burrow in Pleistocene clastic sediments of the Simpson Desert in Australia, about $20 \mathrm{~cm}$ deep, was also interpreted as the wolf spider trace (Hasiotis 2007, fig. 16.7B). An indirect evidence of spider burrows is represented by fossilised roof webs from the Miocene of the Namib Desert, similar in shape to webs that are stretched above the recent burrows of Seothyra in the same region (Pickford 2000).

Potentially, the simple shaft with the basal chamber can be ascribed to the ichnogenus Macanopsis Macsotay, 1967, which basically is produced by crabs in marine settings, and several invertebrates (e.g., beetles, hymenopterans) in continental environments (e.g., Mikuś and Uchman 2013). The recent spider burrows with the side oblique branches (side shafts) are similar to the ichnogenus Psilonichnus Fürsich, 1981 , which is produced by crabs in shore sediments of warmer seas, but it is much larger (Frey et al. 1984).

\section{Lessons from the burrows of Trochosa hispanica and from the literature}

Hils and Hembree (2015) concluded that spider burrows display some common features. They distinguished a few basic types of the burrows, including (1) vertical shafts, (2) vertical shafts with terminal chambers, (3) subvertical shafts, (4) subvertical shafts with terminal chambers, (5) J-shaped burrows, and (6) Y-shaped burrows, and isolated chambers.

The burrows of Trochosa hispanica fall in the second category. They show the same features, i.e. the vertical or nearly vertical orientation, a long shaft and a more or less 
outlined, long basal chamber, a gradual transition from the shaft to the chamber, a more or less circular horizontal section of the shaft, and an elliptical horizontal section of the chamber. They are similar to trace fossils included in the ichnogenus Macanopsis Macsotay, 1967, which can be produced also by many different invertebrates in continental sediments, e.g. by hymenopterans and beetles (see discussion in Mikuś and Uchman 2013). The same refers to most of other spider burrows (Figs. 2, 3, 4), but foremost to the burrows produced by members of the family Lycosidae, which commonly shows the vertical position of the shaft and the presence of the basal chamber (Fig. 4). In contrast, many trapdoor spider burrows (families Nemesiidae, Ctenizidae, Antrodiaetidae) reported in the literature are inclined and located on distinctly inclined surfaces (Fig. 2).

The diversity of second-order morphological details in the studied burrows is high. This concerns distinctiveness of the basal chamber, curvature of the shaft, inclination of the chamber axis to the shaft, or morphometric relationships. Therefore, a population of burrows is recommended for delineation of common features. This is a lesson for potential ichnotaxonomic treatment of possible fossil burrows.

The studied burrows occur in a patch, and burrows with adults and juveniles were located close together. These features are typical of spider burrows (e.g., Coyle 1971; Main 1978; Coyle and Icenogle 1994; Bradley 1996; Canning et al. 2014; Gupta et al. 2015).

Hils and Hembree (2015) stated that spider burrows are elliptical in cross section, but this feature is observed only in the lower part of the burrows of Trochosa hispanica. The mentioned authors stated that spider burrows have no distinguishable lining produced by manipulation of sediment. This is true for the studied burrows and probably for the large majority of other spider burrows, but Coyle and Icenogle (1994) noticed a lining in the burrows of Aliatypus, which was produced by packing of sediment.

It is interesting that individuals of Trochosa hispanica survived a few days after the casting by making a chamber in the not hardened cement in the middle or upper part of the burrow. There is no trace of silk on the chamber margin, but the chamber margin remains smooth. It is not excluded that a large air bubble supported the chamber. There is no evidence of digging into the ambient sediment. It seems that the spiders are adapted to survive a similar, natural catastrophe, such as a filling by sediment or a collapse of their burrows.

The burrowing spiders are much diverse and frequent in warmer climates. The difference is well visible between the Mediterranean region and the middle Europe, where, for instance in Poland, only a few burrowing spiders exist. Thus, spider burrows, especially their abundant occurrence, can be treated as indicators of a warmer climate with a preference to open areas. Strong declining of their range is expected in the colder temperate climatic zones.
Macanopsis or Cylindricum attributed to spiders are typical trace fossils of the Psilonichnus ichnofacies (Frey and Pemberton 1987), but mostly in the coastal sand dune belt (Buatois and Mángano 2011). They are common in overbank fluvial facies of the Scoyenia ichnofacies (Buatois and Mángano 2011), in inland dunes (Ahlbrandt et al. 1978) within the Octopodichnus-Entradichnus ichnofacies, and in the continental, mostly fluvio-lacustrine version of the Skolithos ichnofacies (Scott et al. 2012).

\section{Conclusions}

Some spiders produce burrows in soils and sediments which are their protection domiciles against harsh environmental conditions and play many other life functions. Even if they are studied since eighteenth century, the knowledge on them is still poorly grounded in ichnology. Morphology of the burrows is still poorly known. Many of them are shafts with a basal chamber, for example the burrows of the wolf spider Trochosa hispanica from Albania studied for the first time. Morphological details of this spider burrows may be different. Therefore, a population of burrows is recommended for delineation of common features. The studied burrows are similar to trace fossils included in the ichnogenus Macanopsis. Other spider burrows are similar to Skolithos (simple shafts) or to a small Psilonichnus (shafts with single up-going branches). Diversity of burrowing spiders decreases in the colder temperate climatic zones where their burrows are expected to be rare or absent.

Acknowledgements Reviewers provided helpful comments. A.U. visit in Albania was supported by the Jagiellonian University (DS Funds, K/ZDS/005424).

Open Access This article is distributed under the terms of the Creative Commons Attribution 4.0 International License (http://creativecommons.org/licenses/by/4.0/), which permits unrestricted use, distribution, and reproduction in any medium, provided you give appropriate credit to the original author(s) and the source, provide a link to the Creative Commons license, and indicate if changes were made.

\section{Appendix 1: Taxa of spiders used in the paper (current names according to the World Spider Catalog 2017) and their synonyms used in the discussed literature}
Synonym names used in the dis- Current species names cussed literature (if applicable)
Antrodiaetidae Gertsch, 1940
Aliatypus erebus Coyle, 1974
Aliatypus janus Coyle, 1974
Aliatypus plutonis Coyle, 1974 
Synonym names used in the dis- Current species names cussed literature (if applicable)

Atypidae Thorell, 1870

Atypus abottii

Barychelidae Simon, 1889

Ctenizidae Thorell, 1887

Cteniza fodiens

Mygale ionica

Actinopus adificatorius Westwood

Cyrtaucheniidae Simon, 1889

Rhytidiculus structor Simon, 1899

Idiopidae Simon, 1889

Lycosidae Sundevall, 1833

Lycosa domifex

Lycosa arenicola

Nemesiidae Simon, 1889

Leptopelma cavicula Simon

Nemesia suffosa

Cyrtauchenius elongatus

Theraphosidae Thorell, 1869

Rhechostica hentzi (Girard)
Atypus piceus (Sulzer, 1776)

Sphodros abboti Walckenaer, 1835

Psalistops melanopygius Simon, 1889

Cteniza sauvagesi (Rossi, 1788)

Cyrtocarenum cunicularium

(Olivier, 1811)

Ummidia aedificatoria (Westwood, 1840)

Ummidia Thorell, 1875

Cyclocosmia Ausserer, 1871

Ancylotrypa Simon, 1889

Rhytidicolus structor Simon, 1889

Gorgyrella inermis Tucker, 1917

Allocosa brasiliensis (Petrunkevitch, 1910)

Geolycosa domifex (Hancock, 1899)

Geolycosa hubbelli Wallace, 1942

Geolycosa missouriensis (Banks, 1895)

Geolycosa turricola (Treat, 1880)

Geolycosa xera archboldi

McCrone, 1963

Hogna lenta (Hentz, 1844)

Lycosa tarantula (Linneus, 1758)

Lycosa Latreille, 1804

Nemesia caementaria (Latreille, 1799)

Nemesia caranhaci Decae, 1995

Nemesia cavicola (Simon, 1889)

Nemesia daedali Decae, 1995

Nemesia dubia O. Pickard-Cambridge, 1874

Nemesia eleanora O. Pickard-

Cambridge, 1873

Nemesia elongata (Simon, 1873)

Nemesia manderstjernae L. Koch, 1871

Aphonopelma hentzi (Girard, 1852)

Brachypelma vagans (Ausserer, 1875)
Synonym names used in the dis- Current species names cussed literature (if applicable)

\begin{tabular}{lc}
\hline & Nesiergus insulanus Simon, 1903 \\
Mygale (Theraphosa) blondii & Theraphosa blondi (Latreille, \\
& 1804 ) \\
Stothis astuta Simon & Trichopelma astutum (Simon, \\
Stothis cenobita Simon & 1889 ) \\
& Trichopelma coenobita (Simon, \\
& $1889)$
\end{tabular}

Segestriidae Simon, 1893

Ariadna Audouin, 1826

Eresidae C.L. Koch, 1845

Seothyra Purcell, 1903

\section{References}

Ahlbrandt T, Andrews S, Gwynne DT (1978) Bioturbation of eolian deposits. J Sed Petrol 48:839-848

Aisenberg A, Peretti AV (2011) Male burrow digging in a sex rolereversed spider inhabiting water-margin environments. Bull $\mathrm{Br}$ Arach Soc 15:201-204

Aisenberg A, González M, Laborda Á, Postiglioni R, Simó M (2011) Spatial distribution, burrow depth and temperature: implications for the sexual strategies in two Allocosa wolf spiders. Stud Neotrop Fauna Env 46:147-152

Albín A, Simó M, Aisenberg A (2015) Characterisation of burrow architecture under natural conditions in the sand-dwelling wolf spider Allocosa brasiliensis. J Nat Hist 50:201-209. https://doi. org/10.13156/arac.2011.15.6.201

Alf RM (1968) A spider trackway from the coconino formation, seligman, Arizona. Bull South Calif Acad Sci 67:125-128

Alpert SP (1974) Systematic review of the genus Skolithos. J Paleont 49:509-521

Audouin MV (1833) Observations sur la structure du nid de l'araignée pionnière. Ann Soc Entom Fr 2:69-85

Audouin V (1837) Note sur la demeure d'une Araignée maçonne originaire de l'Amérique du Sud. Ann Sci Nat 2(Sér 7):227-231

Autorësh G (1991) Gjeografia fizike e Shqipërisë. Vëllimi i dytë. Vështrim fiziko-gjeograffik krahinor. Akademia e Shkencave, Qendra e Studimeve Gjeografike, Tiranë, p 592

Bates HW (1864) The naturalist on the river Amazons, 2nd edn. Murray, London, $\mathrm{p} 466$

Birkhofer K, Moldrzyk U (2003) Burrow construction in three Tunisian desert spiders (Araneae: Sparassidae, Lycosidae, Filistatidae). Kaupia, Darmstädter Beit Naturges 12:111-118

Bond JE, Coyle FA (1995) Observations on the natural history of an Ummidia trapdoor spider from Costa Rica (Araneae, Ctenizidae). J Arachnol 23:157-164

Bradley RA (1996) Foraging activity and burrow distribution in the Sydney brown trapdoor spider (Misgolas rapax Karsch: Idiopidae). J Arachnol 24:58-67

Bromley RG (1981) Concepts in ichnotaxonomy illustrated by small round holes in shells. Acta Geol Hisp 16:55-64

Browne P (1756) The Civil and natural history of JamaicaT. Osborne and J. Shipton: London, p 503

Bryson HR (1939) Identification of soil insects by their burrow characteristics. Trans Kansas Acad Sci 42:245-253 
Buatois LA, Mángano MG (2011) Ichnology: organism-substrate interactions in space and time. Cambridge University Press, Cambridge, p 358

Canning G, Reilly BK, Dippenaar-Schoeman AS (2014) Burrow structure and microhabitat characteristics of Nesiergus insulanus (Araneae: Theraphosidae) from Frégate Island, Seychelles. J Arachnol 42:293-298

Carre JE (2003) Ecology of two burrowing wolf spiders (Araneae: Lycosidae) syntopic in Florida scrub: burrow/body size relationships and habitat preferences. J Kansas Ent Soc 76:16-30

Carrel JE (2008) Differential survival of Geolycosa xera archboldi and G. hubbelli (Araneae, Lycosidae) after fire in Florida scrub. J Arachnol 36:595-599

Chikhale MP, Santape GB (2015) Burrowing habit play thermoregulation role in Geolycosa Montgomery TH (1904 (Araneae, Lycosidae). Int J Sci Res 4:2162-2163

Conti E, Costa G, Marletta A, Viscuso R, Vitale DGM (2015) The chorion of eggs in a Namibian Ariadna species (Araneae: Segestriidae): morphological and SEM analyses. J Arachnol 43:224-227. https://doi.org/10.1636/M14-72

Corey DT (1991) Burrow structure and placement in Geolycosa xera (Araneae: Lycosideae). Florida Sci 54:125-128

Costa G, Petralia A, Conti E, Hanel C, Seely MK (1993) Seven stone spiders on the gravel plains of the Namib Desert. Boll Gioenia Sci Nat Catania 26(345):77-83

Coyle FA (1971) Systematics and natural history of the mygalomorph spider genus Antrodiaetus and related genera (Araneae: Antrodiaetidae). Bull Mus Comp Zool 141:269-402

Coyle FA, Icenogle WR (1994) Natura history of the Californian trapdoor spider genus Aliatypus (Araneae, Antrodiaetidae). J Arachnol 22:225-255

Curran AH, White B (1991) Trace fossils of shallow subtidal to dunal ichnofacies in Bahamian Quaternary carbonates. Palaios 6:498-510

Davis RB, Minter NJ, Braddy SJ (2007) The neoichnology of terrestrial arthropods. Palaeogeogr Palaeoclimat Palaeoecol 255:284-307. https://doi.org/10.1016/j.palaeo.2007.07.013

De Simone GA, Aisenberg A, Peretti AV (2015) Female and juvenile burrow digging in Allocosa brasiliensis, a South American sand-dwelling wolf spider. Arachnology 16:276-280. https://doi. org/10.13156/arac.2015.16.8.276

Decae AE (1995) Two new trapdoor spider species in the genus Nemesia Audouin, 1827 and the first report of this genus from Greece (Araneae, Mygalomorphae, Nemesiidae). Deinsia 2:1-8

Decae AE (1996) Variation in burrow morphology of Mediterranean trapdoor spiders (Ctenizidae, Cyrtaucheniidae, Nemesiidae). Rev Suisse Zool Vol Hors Sér 1:135-140

Dunlop JA, Braddy SJ (2011) Cteniza bavincourti and the nomenclature of arachnid-related trace fossils. J Arachnol 39:250-257

Fernandes ACS, Borghi L, Carvalho IS (1992) Icnofósseis de Artropodes na Formação Resende (Bacia de Resende, RJ). Anais Acad Brasil Ciên 64:269-275

Fitzgerald PG, Barret PJ (1986) Skolithos in a Permian braided river deposit, southern Vicoria Land, Antarctica. Palaeogeogr Palaeoclimate Palaeoecol 52:237-247

Formanowicz DR Jr, Ducey PK (1991) Burrowing behavior and soil manipulation by a tarantula, Rhechostica hentzi (Girard, 1853) (Araneida: Theraphosidae). Can J Zool 69:2916-2918

Frey RW, Pemberton SG (1987) The Psilonichnus ichnocoenose, and its relationship to adjacent marine and nonmarine ichnocoenoses along the Georgia coast. Bull Can Petrol Geol 36:333-357

Frey RW, Curran AH, Pemberton SG (1984) Trace making activities of crabs and their environmental significance: the ichnogenus Psilonichnus. J Paleont 58:333-350

Fürsich FT (1981) Invertebrate trace fossils from the Upper Jurassic of Portugal. Com Serv Geol Portugal 67:153-168
Gertsch WJ (1949) American spiders. D. Van Nostrand Company, Toronto, p 285

Grup Autorësh (1990) Gjeografia fizike e Shqipërisë. Vëllimi i parë. Vështrim i përgjithshëm fiziko - gjeografik. Tiranë: Akademia e Shkencave, Qendra e Studimeve Gjeografike, p 400

Gupta N, Keshari Das S, Siliwal M et al (2015) Natural history of the trapdoor spider Idiops joida Gupta, 2013 (Araneae: Idiopidae) from the Western Ghats in India. J Asia Pac Biodiv 8:38-42. https://doi.org/10.1016/j.japb.2015.01.004

Gwynne DT (1979) Nesting biology of the spider wasps (Hymenoptera: Pompilidae) which prey on burrowing wolf spiders (Araneae: Lycosidae, Geolycosa). J Nat Hist 13:681-692

Haldeman SS (1840) Supplement to number one of "A monograph of the Limniades, and other freshwater univalve shells of North America", containing descriptions of apparently new animals in different classes, and names and characters of the subgenera in Paludina and Anculosa. Dobson, Philadelfia, p 3

Hamilton DE, McIntyre NE, Densmore LD III (2012) Using implanted passive integrated transponders to monitor long-term burrow fidelity in a theraphosid spider, Aphonopelma hollyi. Southwest Nat 57:144-147. https://doi. org/10.1894/0038-4909-57.2.144

Hancock JL (1899) The castle-building spider. Ent News 10:23-29

Hasiotis ST (2002) Continental trace fossils. SEPM Short Course Notes $51: 132 \mathrm{pp}$

Hasiotis ST (2007) Continental ichnology: fundamental processes and controls on trace fossil distribution. The continental realm. In: Miller W III (ed) Trace fossils: concepts, problems, prospects. Elsevier, Amsterdam, pp 268-284

Hasiotis ST, Bourke MC (2006) Continental trace fossils and museum exhibits: displaying burrows as organism behaviour frozen in time. Geol Curator 8:211-226

Henschel JR (1990) The biology of Leucorchestris arenicola (Araneae: Heteropodidae), a burrowing spider of the Namib dunes. In: Seely MK (ed) Namib ecology: 25 years of Namib research. Transvaal Mus Monogr no7, pp 115-127. Transvaal Mus, Pretoria

Hepner M, Milasowszky N (2006) Morphological separation of the central European Trochosa females (Araneae, Lycosidae). Arach Mitt 31:1-7

Hils J, Hembree DI (2015) Neoichnology of the burrowing spiders Gorgyrella inermis (Mygalomorphae: Idiopidae) and Hogna lenta (Araneomorphae: Lycosidae). Palaeontologia Electronica 18.1.7A, 1-62. 4.069 MB, http://palaeo-electronica.org/content/ pdfs/500.pdf. Accessed 30 March 2016

Humphreys WF (1978) The thermal biology of Geolycosa godeffroyi and other burrow inhabiting Lycosidae (Araneae) in Australia. Oecologia 31:319-347

Leriche M (1910) Sur la présence de tubulures analogues aux terriers des Mygales dans des grès landéniens du Nord de la France. Ann Soc Géol Nord 39:371-376

Leroy A, Leroy J (2005) Notes on the natural history of a trapdoor spider Ancylotrypa Simon (Araneae, Cyrtaucheniidae) that constructs a spherical burrow plug. J Arach 33:558-561

Linck O (1949) Lebens-Spuren aus dem Schilfsandstein (Mittlerer Keuper, km2), Nordwest-Württembergs und ihre Bedeutung für die Bildungsgeschichte der Stufe. Jahresh Ver Vaterländ Naturk Württemberg 97-101:1-100

Lubin YD, Henschel JR (1990) Foraging at the thermal limit: burrowing spiders (Seothyra, Eresidae) in the Namib desert dunes. Oecologia 84:461-467

Machkour M'Rabet S, Hénaut Y, Sepúlveda A, Rojo R, Calmé S, Geissen V (2007) Soil preference and burrow structure of an endangered tarantula, Brachypelma vagans (Mygalomorphae: Theraphosidae). J Nat Hist 41(17-20):1025-1033

Macsotay O (1967) Huellas problematicas y su valor paleoecologico en Venezuela. Géos 16:7-39 
Main BY (1978) Biology of the arid-adapted Australian trapdoor spider Anidiops villosus (Rainbow). Bull Br Arach Soc 4:161-175

Main BY (1993) From flood avoidance to foraging: adaptive shifts in trapdoor spider behavior. Mem Queensl Mus 33:599-606

Marshall SD (1995) Natural history, activity patterns, and relocation rates of a burrowing wolf spider: Geolycosa xera archboldi (Araneae, Lycosidae). J Arachnol 23:65-70

McCook HC (1885) Tenants of an old farm, leaves from a note-book a naturalist. Fords, Howard, and Hulbert, New York, p 460

McCook HC (1888) Nesting habits of the American purse-web spider. Proc Acad Nat Sci Philadelphia 40:203-220

McCook HC (1890) Defences of burrowing spiders. Pop Sci Month 38:189-193

Mikuś P, Uchman A (2013) Beetle burrows with a terminal chamber: a contribution to the knowledge of the trace fossil Macanopsis in continental sediments. Palaios 28:403-413. https://doi. org/10.2110/palo.2012.p12-129r

Miller GL, Miller PR (1984) Correlations of burrow characteristics and body size in burrowing wolf spiders (Araneae: Lycosidae). Florida Ent 67:314-317

Moggridge JT (1873) Harvesting ants and trapdoor spiders. Notes and observations in their habits and dwellings. L. Reeve, London, $p$ 156

Moggridge JT (1874) A supplement to harvesting ants and trapdoor spiders. L. Reeve, London, pp 157-304

Nentwig W, Blick T, Gloor D, Hänggi A, Kropf C (2016) Spiders of Europe. www.araneae.unibe.ch. Version 03. 2016. Checked 25 March 2016

Nørgaard T (2005) Nocturnal navigation in Leucorchestris arenicola (Araneae, Sparassidae). J Arachnol 33:533-540

Penney D, Selden PA (2011) fossil spiders: the evolutionary history of a mega-diverse order. Siri Scientific Press, Manchester, p 128

Pickford M (2000) Fossil spider's webs from the Namib Desert and the antiquity of Seothyra (Araneae, Eresidae). Ann Paléont $86: 147-155$

Poteat WL (1890) A tube-building spider. Notes on the architectural and feeding habits of Atypus niger Hentz(?). J Elisha Mitchell Sci Soc 6(2) (for 1889):134-147

Ratcliffe BC, Fagerstrom JA (1980) Invertebrate lebensspuren of Holocene floodplains: their morphology, origin and paleoecological significance. J Paleont 54:614-630

Saunders SS (1842a) Description of species of Mygale, from Ionia with its nest. Trans Ent Soc London 3 (part 3):160-164

Saunders SS (1842b) Additional observations on the habits of Mygale. Trans Ent Soc London 3 (part 3):165-169

Schmerge JD, Riese DJ, Hasiotis ST (2013) Vinegaroon (Arachnida: Thelyphonida: Thelyphonidae) trackway production and morphology: Implications for media and moisture control on trackway morphology and a proposal for a novel system of interpreting arthropod trace fossils. Palaios 28:116-128. https://doi. org/10.2110/palo.2012.p12-012r
Scott JJ, Buatois LA, Mángano MG (2012) Lacustrine environment. In: Knaust D, Bromley RG (eds) Trace fossils as indicators of sedimentary environment. Develop Sed 64:379-417

Simon E (1870) Aranéides noveaux ou peu connus du midi de l'Europe. Mém Soc R Sci Liège 2(3):271-358

Simon ME (1873) Trois espèces françaises de genere Atypus Latr. Ann Soc Ent Fr Sér 5(3):109-116

Simon ME (1889) Voyage de M. E. Simon au Venezuela; Arachnides. Ann Soc Ent Fr Sér 6 9:169-220

Smith JJ, Hasiotis ST, Kraus MJ, Woody DT (2008) Relationship of floodplain ichnocoenoses to paleopedology, paleohydrology, and paleoclimate in the Willwood Formation, Wyoming, during the Paleocene-Eocene Thermal Maximum. Palaios 23:683-699

Suter RB, Stratton GE, Miller PR (2011) Mechanics and energetics of excavation by burrowing wolf spiders, Geolycosa spp. J Insect Sci 11, article 22:1-15. https://doi.org/10.1673/031.011.0122

Thaler K, Buchar J, Knoflach B (2000) Notes on wolf spiders from Greece (Araneae, Lycosidae). Linzer Biol Beitr 32:1071-1091

Uchman A, Vrenozi B, Muceku B (2015) Burrows of the wolf spider Trochosa hispanica Simon 1870 from Albania. In: Saber H, Lagnaoui A, Belahmira A (eds) First International Congress on Continental Ichnology [ICCI-2015]. Proc Abstr, Faculty Sci, Chouaïb Doukkali Univ April 21-25, 2015, El Jadida, Morocco El Jadida, Univ Chouaïb Doukkali, p 67

Vaillant L (1909) Observations paléontologiques faites dans les Sables éocènes landéniens aux environs d'Arras. Bull Soc Géol Fr 4e Sér 9:277-282

Vrenozi B, Deltshev C (2012) Spiders (Araneae) from Vora hills, Albania. Albanian J Agricult Sci 11:179-183

Vrenozi B, Jäger P (2012) A faunistic study on ground dwelling spiders (Araneae) in the Tirana district, Albania. Arachnol Mitt 44:81-87

Westwood JO (1842) Observations on the species of spiders which inhabit cylindrical tubes covered by a moveable trap-door. Trans Ent Soc London 3 (part 3):170-182

Williams JL, Moya-Laraño J, Wise DH (2006) Burrow decorations as antipredatory devices. Behav Ecol 17(4):586-590. https://doi. org/10.1093/beheco/ark003

Wisshak M, Kroh A, Bertling M, Knaust D, Nielsen JK, Jagt JWM, Neumann C, Nielsen KSS (2015) In defence of an iconic ichnogenus - Oichnus Bromley, 1981. Ann Soc Geol Pol 85:445-451. https://doi.org/10.14241/asgp.2015.029

World Spider Catalog (2017) World Spider Catalog. Natural History Museum Bern: http://wsc.nmbe.ch, version 18.5. Accessed 5 Nov 2017

Zdruli P, Lushaj S, Pezzuto A, Fanelli D, D’Amico O, Filomeno O, De Santis S, Todorovic M, Nerilli E, Dedaj K, Seferi B (2002) Preparing a georeferenced soil database for Albania at scale 2: 2500000 using the European soil Bureau Manual of procedures. CIHEAM Options Méditerranéennes: Série A: Séminaires Méditerranéens 50:135-144 